\title{
Early Emergence of Dickeya solani Revealed by Analysis of Dickeya Diversity of Potato Blackleg and Soft Rot Causing Pathogens in Switzerland
}

\author{
Jacques Pédron ${ }^{1}$, Santiago Schaerer ${ }^{2}$, Isabelle Kellenberger ${ }^{2}$ and Frédérique Van Gijsegem ${ }^{1, *}$ \\ 1 Institute of Ecology and Environmental Sciences-Paris, Sorbonne Université, INRAE, 4 Place Jussieu, \\ F-75252 Paris, France; jacques.pedron@upmc.fr \\ 2 Agroscope Changins, Domaine de Recherche Protection des Végétaux, CH-1260 Nyon, Switzerland; \\ santiago.schaerer@agroscope.admin.ch (S.S.); isabelle.kellenberger@agroscope.admin.ch (I.K.) \\ * Correspondence: vangijse@agroparistech.fr
}

check for

updates

Citation: Pédron, J.; Schaerer, S.; Kellenberger, I.; Van Gijsegem, F. Early Emergence of Dickeya solani Revealed by Analysis of Dickeya Diversity of Potato Blackleg and Soft Rot Causing Pathogens in Switzerland. Microorganisms 2021, 9 , 1187. https://doi.org/10.3390/ microorganisms 9061187

Academic Editor: Denis Faure

Received: 26 March 2021

Accepted: 21 May 2021

Published: 31 May 2021

Publisher's Note: MDPI stays neutral with regard to jurisdictional claims in published maps and institutional affiliations.

Copyright: (c) 2021 by the authors. Licensee MDPI, Basel, Switzerland. This article is an open access article distributed under the terms and conditions of the Creative Commons Attribution (CC BY) license (https:/ / creativecommons.org/licenses/by/ $4.0 /)$.

\begin{abstract}
Blackleg and soft rot in potato caused by Pectobacterium and Dickeya enterobacteral genera are among the most destructive bacterial diseases in this crop worldwide. In Europe, over the last century, Pectobacterium spp. were the predominant causal agents of these diseases. As for Dickeya, before the large outbreak caused by D. solani in the 2000s, only D. dianthicola was isolated in Europe. The population dynamics of potato blackleg causing soft rot Pectobacteriaceae was, however, different in Switzerland as compared to that in other European countries with a high incidence (60 up to 90\%) of Dickeya species (at the time called Erwinia chrysanthemi) already in the 1980s. To pinpoint what may underlie this Swiss peculiarity, we analysed the diversity present in the E. chrysanthemi Agroscope collection gathering potato isolates from 1985 to 2000s. Like elsewhere in Europe during this period, the majority of Swiss isolates belonged to D. dianthicola. However, we also identified a few isolates, such as D. chrysanthemi and D. oryzeae, two species that have not yet been reported in potatoes in Europe. Interestingly, this study allowed the characterisation of two "early" D. solani isolated in the 1990s. Genomic comparison between these early D. solani strains and strains isolated later during the large outbreak in the 2000s in Europe revealed only a few SNP and gene content differences, none of them affecting genes known to be important for virulence.
\end{abstract}

Keywords: comparative genomics; blackleg; soft rot Pectobacteriaceae; Swiss Agroscope collection

\section{Introduction}

Potatoes are cultivated all over the world, as far north as Finland near the Arctic Circle and far south as New Zealand, and in various environmental conditions from the South American Altiplano to the Neguev Desert in Israel; it is the fourth main food crop worldwide. In seed potato production, besides bacterial wilt caused by Ralstonia solanacearum and, to a lesser degree, bacterial ring rot and wilt caused by Clavibacter sepedonicus, the most destructive bacterial diseases are blackleg and soft rot provoked by the genera Pectobacterium and Dickeya [1]. In several European countries, these soft rot Pectobacteriaceae (SRP) are responsible for most of the declassifications and rejections of potato seed lots [2]. The main route of infection is via contaminated potato seeds, where the bacteria may remain latently at a low level until the environmental conditions become favourable for expression of the virulence factors and extensive bacterial multiplication. The most important factor is the production and secretion of a battery of plant cell wall degrading enzymes that allow the maceration of plant tissues, leading to cell lysis and liberation of the cell content. However, SRP virulence relies on several other factors that allow these bacteria to adapt to environmental changes encountered in planta and to face the stresses produced by plant defence responses [3-5].

The population dynamics of the SRP causing blackleg and tuber rot in potato is well described in Europe. Historically, in most European countries, the causal agent of potato 
blackleg and soft rot was the cold-tolerant P. atrosepticum [6]. The first report of Dickeya (at the time called Erwinia chrysanthemi) recovered from potatoes dates from the 1970s, but losses attributable to this pathogen have remained generally low and sporadic [7]. In the 1980-1990s, surveys performed at the NAK in The Netherlands showed a more complex situation with a greater incidence of Dickeya (around 20\%) and the occurrence of members of the so-called Pectobacterium carotovorum complex (at the time called Erwinia carotovora) (E. G. de Haan, NAK, personal communication). Analysis of Erwinia chrysanthemi strains isolated from potatoes in Europe during this period [8,9] appeared to be mostly D. dianthicola, a species first isolated in ornamentals in the late 1950s in UK and Denmark [10]. From 2005 to 2013, a large outbreak in seed potatoes ravaged Europe. It was accompanied by a high incidence of Dickeya that reached, for example, up to 70\% in The Netherlands (E. G. de Haan, NAK, personal communication). From 2014, Dickeya was progressively replaced by $P$. brasiliense that now is isolated from more than $80 \%$ of blackleg-suffering plants (E. G. de Haan, NAK, personal communication).

The 2005 outbreak coincided with the isolation of a new Dickeya species, D. solani, which has commonly been isolated from seed potato tubers in The Netherlands-even though a wide range of different cultivars and locations have been sampled-but has also appeared to predominate in other European countries and Israel [7,11-13].

The population dynamics was different in Switzerland since Dickeya spp. have been described as being the cause of blackleg in $60-90 \%$ of tested diseased potato plants since the 1980s [14,15]. Thus, we took advantage of the constitution in the Swiss Agroscope of a collection of former Erwinia chrysantemi since the 1980s to analyse the history of Dickeya diversity in potatoes in this particular case.

\section{Material and Methods}

\subsection{Bacterial Strains, Culture Conditions, DNA Extraction and Species Identification}

The bacterial strains used in this study are presented in Table 1 . They were isolated from diseased stems belonging to potato plants eliciting black leg symptoms in the multiplication fields or from rotted potato tubers. Stems or tubers were washed under running tap water, blotted dry with paper towels and cut open longitudinally. Small pieces (20-40 mg) of tissue were removed at the edge of the rotting lesions, close to healthy tissue. Those pieces were further shredded in $2 \mathrm{~mL}$ of sterile distilled water and left to macerate for $10 \mathrm{~min}$. Aliquots from such suspensions were streaked onto crystal violet pectate (CVP) medium and tested for cavity formation following incubation at $27^{\circ} \mathrm{C}$ for $24-48 \mathrm{~h}$. Bacteria were re-isolated from characteristic pits, plated onto KB medium, and incubated at $27^{\circ} \mathrm{C}$ for $24-48 \mathrm{~h}$. Colonies were further characterised by biochemical tests $[14,15]$. They were routinely grown on $\mathrm{LB}^{-}$medium consisting of $\mathrm{LB}$ medium without added $\mathrm{NaCl}(10 \mathrm{~g} / \mathrm{L}$ peptone, $5 \mathrm{~g} / \mathrm{L}$ yeast extract).

Total bacterial DNA was extracted using the Wizard genomic DNA purification kit (Promega) following manufacturer's protocol, and determination of appurtenance to Dickeya species was determined by PCR amplification of the housekeeping gene gap $A$ using the gapA-7-F and gapA-938-R primer set and Sanger sequencing of the gapA amplicon [16] using the Eurofins Custom DNA Sequencing PlateSeq Service. The phylogenetic tree was reconstructed from the gapA nucleotide sequences. The gapA genes were aligned using MUSCLE [17] software and were filtered using the GBLOCK tool [18]. The alignments were used for building a phylogenetic tree with the PhyML algorithm based on the Tamura-Nei model [19] with SeaView software [20], with 200 bootstrap replications. 
Table 1. Bacterial strains analysed in this study.

\begin{tabular}{|c|c|c|c|c|}
\hline Strain Name & Isolation Year & Origin * & Host Plant & Species Definition \\
\hline E. chrysanthemi $\mathrm{CH} 85 / 54$ & 1985 & $\mathrm{CH}$ & S. tuberosum cv. Ostara & D. dianthicola \\
\hline E. chrysanthemi $\mathrm{CH} 86 / 31-1$ & 1986 & $\mathrm{CH}$ & S. tuberosum cv. Désirée & D. dianthicola \\
\hline E. chrysanthemi CH86/31-5 & 1986 & $\mathrm{CH}$ & S. tuberosum cv. Désirée & D. dianthicola \\
\hline E. chrysanthemi CH86/33-14 & 1986 & $\mathrm{CH}$ & S. tuberosum cv. Bintje & D. dianthicola \\
\hline E. chrysanthemi CH86/40-7 & 1986 & $\mathrm{CH}$ & S. tuberosum cv. Désirée & D. dianthicola \\
\hline E. chrysanthemi $\mathrm{CH} 87 / 29$ & 1987 & $\mathrm{CH}$ & S. tuberosum & D. dianthicola \\
\hline E. chrysanthemi $\mathrm{CH} 87 / 88$ & 1987 & $\mathrm{CH}$ & S. tuberosum cv. Désirée & Rhanella aquatilis \\
\hline E. chrysanthemi $\mathrm{CH} 86 / 33$ & 1986 & $\mathrm{CH}$ & S. tuberosum cv. Désirée & D. dianthicola \\
\hline E. chrysanthemi CH87/89-26 & 1987 & $\mathrm{CH}$ & S. tuberosum cv. Désirée & D. dianthicola \\
\hline E. chrysanthemi CH87/89-27 & 1987 & $\mathrm{CH}$ & S. tuberosum cv. Désirée & D. dianthicola \\
\hline E. chrysanthemi $\mathrm{CH} 88 / 23$ & 1988 & $\mathrm{CH}$ & S. tuberosum cv. Désirée & D. dianthicola \\
\hline E. chrysanthemi $\mathrm{CH} 88 / 26$ & 1988 & $\mathrm{CH}$ & S. tuberosum cv. Bintje & D. dianthicola \\
\hline E. chrysanthemi $\mathrm{CH} 88 / 33$ & 1988 & $\mathrm{CH}$ & S. tuberosum cv. Désirée & Rhanella aquatilis \\
\hline E. chrysanthemi $\mathrm{CH} 88 / 39$ & 1988 & $\mathrm{CH}$ & S. tuberosum cv. Désirée & D. dianthicola \\
\hline E. chrysanthemi CH88/49 & 1988 & $\mathrm{CH}$ & S. tuberosum cv. Désirée & D. dianthicola \\
\hline E. chrysanthemi $\mathrm{CH} 88 / 50$ & 1988 & $\mathrm{CH}$ & S. tuberosum cv. Désirée & D. dianthicola \\
\hline E. chrysanthemi $\mathrm{CH} 88 / 51$ & 1988 & $\mathrm{CH}$ & S. tuberosum cv. Désirée & D. dianthicola \\
\hline E. chrysanthemi $\mathrm{CH} 88 / 52-2$ & 1988 & $\mathrm{CH}$ & S. tuberosum cv. Désirée & D. dianthicola \\
\hline E. chrysanthemi CH88/53 & 1988 & $\mathrm{CH}$ & S. tuberosum cv. Désirée & D. dianthicola \\
\hline E. chrysanthemi CH88/61 & 1988 & $\mathrm{CH}$ & S. tuberosum cv. Désirée & D. dianthicola \\
\hline E. chrysanthemi $\mathrm{CH} 88$ /63-2 & 1988 & $\mathrm{CH}$ & S. tuberosum cv. Désirée & D. dianthicola \\
\hline E. chrysanthemi CH88/64 & 1988 & $\mathrm{CH}$ & S. tuberosum cv. Désirée & D. dianthicola \\
\hline E. chrysanthemi $\mathrm{CH} 88 / 65$ & 1988 & $\mathrm{CH}$ & S. tuberosum cv. Urgenta & D. dianthicola \\
\hline E. chrysanthemi CH88/66 & 1988 & NL & S. tuberosum & D. dianthicola \\
\hline E. chrysanthemi $\mathrm{CH} 88 / 67$ & 1988 & $\mathrm{CH}$ & S. tuberosum & D. dianthicola \\
\hline E. chrysanthemi $\mathrm{CH} 88 / 68$ & 1988 & $\mathrm{CH}$ & S. tuberosum & D. dianthicola \\
\hline E. chrysanthemi $\mathrm{CH} 88 / 70$ & 1988 & $\mathrm{CH}$ & S. tuberosum cv. Désirée & D. dianthicola \\
\hline E. chrysanthemi $\mathrm{CH} 88 / 72$ & 1988 & $\mathrm{CH}$ & S. tuberosum cv. Granola & D. dianthicola \\
\hline E. chrysanthemi $\mathrm{CH} 88 / 75$ & 1988 & $\mathrm{CH}$ & S. tuberosum cv. Aula & D. dianthicola \\
\hline E. chrysanthemi $\mathrm{CH} 88 / 85$ & 1988 & $\mathrm{CH}$ & S. tuberosum cv. Eba & D. dianthicola \\
\hline E. chrysanthemi CH88/111-3 & 1988 & $\mathrm{CH}$ & S. tuberosum cv. Désirée & D. dianthicola \\
\hline E. chrysanthemi CH88/141 & 1988 & $\mathrm{CH}$ & S. tuberosum cv. Désirée & D. dianthicola \\
\hline E. chrysanthemi CH88/161-1 & 1988 & $\mathrm{CH}$ & S. tuberosum cv. Désirée & D. dianthicola \\
\hline E. chrysanthemi CH88/161-2 & 1988 & $\mathrm{CH}$ & S. tuberosum cv. Désirée & P. versatile \\
\hline E. chrysanthemi $\mathrm{CH} 88$ /166 & 1988 & $\mathrm{CH}$ & S. tuberosum cv. Désirée & D. dianthicola \\
\hline E. chrysanthemi CH88/169-1 & 1988 & $\mathrm{CH}$ & S. tuberosum cv. Désirée & D. dianthicola \\
\hline E. chrysanthemi $\mathrm{CH} 88 / 169-3$ & 1988 & $\mathrm{CH}$ & S. tuberosum cv. Désirée & D. dianthicola \\
\hline E. chrysanthemi CH88/172-2 & 1988 & $\mathrm{CH}$ & S. tuberosum cv. Désirée & D. dianthicola \\
\hline E. chrysanthemi CH88/196 & 1988 & $\mathrm{CH}$ & S. tuberosum cv. Désirée & D. dianthicola \\
\hline E. chrysanthemi CH88/197 & 1988 & $\mathrm{CH}$ & S. tuberosum cv. Désirée & D. dianthicola \\
\hline E. chrysanthemi $\mathrm{CH} 89 / 48$ & 1989 & $\mathrm{CH}$ & S. tuberosum cv. Eba & D. dianthicola \\
\hline E. chrysanthemi $\mathrm{CH} 89 / 50$ & 1989 & $\mathrm{CH}$ & S. tuberosum cv. Eba & D. dianthicola \\
\hline E. chrysanthemi $\mathrm{CH} 89 / 53$ & 1989 & $\mathrm{CH}$ & S. tuberosum cv. Urgenta & D. dianthicola \\
\hline E. chrysanthemi $\mathrm{CH} 89 / 55$ & 1989 & $\mathrm{CH}$ & S. tuberosum cv. Nicola & D. dianthicola \\
\hline E. chrysanthemi CH90/95-2-4 & 1990 & $\mathrm{CH}$ & S. tuberosum cv. Eba & D. dianthicola \\
\hline E. chrysanthemi CH90/105-1-3 & 1990 & $\mathrm{CH}$ & S. tuberosum cv. Ostara & D. dianthicola \\
\hline E. chrysanthemi CH90/110-7-1 & 1990 & $\mathrm{CH}$ & S. tuberosum cv. Bintje & D. dianthicola \\
\hline E. chrysanthemi CH90/141 & 1990 & $\mathrm{CH}$ & S. tuberosum cv. Urgenta & D. dianthicola \\
\hline E. chrysanthemi $\mathrm{CH} 90 / 140$ & 1990 & $\mathrm{CH}$ & S. tuberosum cv. Bintje & D. dianthicola \\
\hline E. chrysanthemi CH91/53-4 & 1991 & $\mathrm{CH}$ & S. tuberosum cv. Désirée & P. versatile \\
\hline E. chrysanthemi CH91/70-1 & 1991 & $\mathrm{CH}$ & S. tuberosum cv. Eba & D. chrysanthemi \\
\hline E. chrysanthemi CH91/71-2 & 1991 & $\mathrm{CH}$ & S. tuberosum cv. Eba & D. oryzeae \\
\hline E. chrysanthemi CH91/75-1 & 1991 & $\mathrm{CH}$ & S. tuberosum cv. Eba & P. parmentieri \\
\hline E. chrysanthemi CH91/83-2 & 1991 & $\mathrm{CH}$ & S. tuberosum cv. Désirée & D. dianthicola \\
\hline E. chrysanthemi CH91/87-1 & 1991 & $\mathrm{CH}$ & S. tuberosum cv. Désirée & D. dianthicola \\
\hline E. chrysanthemi $\mathrm{CH} 91 / 111$ & 1991 & $\mathrm{CH}$ & S. tuberosum cv. Urgenta & D. dianthicola \\
\hline E. chrysanthemi $\mathrm{CH} 91 / 116-8$ & 1991 & $\mathrm{CH}$ & S. tuberosum cv. Désirée & D. dianthicola \\
\hline E. chrysanthemi CH91/49-9 & 1991 & $\mathrm{CH}$ & S. tuberosum cv. Eba & D. dianthicola \\
\hline E. chrysanthemi CH91/101-4 & 1991 & $\mathrm{CH}$ & S. tuberosum cv. Désirée & D. dianthicola \\
\hline E. chrysanthemi CH91/94-1 & 1991 & $\mathrm{CH}$ & S. tuberosum cv. Eba & D. dianthicola \\
\hline E. chrysanthemi CH91/97-1 & 1991 & $\mathrm{CH}$ & S. tuberosum cv. Nicola & D. dianthicola \\
\hline E. chrysanthemi $\mathrm{CH} 91 / 302$ & 1991 & $\mathrm{CH}$ & S. tuberosum cv. Désirée & D. dianthicola \\
\hline E. chrysanthemi $\mathrm{CH} 91 / 308$ & 1991 & $\mathrm{CH}$ & S. tuberosum cv. Désirée & D. dianthicola \\
\hline E. chrysanthemi $\mathrm{CH} 93 / 38-23-1$ & 1993 & $\mathrm{CH}$ & S. tuberosum cv. Sirtema & D. dianthicola \\
\hline E. chrysanthemi CH93/38-26-2 & 1993 & $\mathrm{CH}$ & S. tuberosum cv. Sirtema & D. dianthicola \\
\hline E. chrysanthemi CH93/40-8-1 & 1993 & $\mathrm{CH}$ & S. tuberosum cv. Ostara & D. dianthicola \\
\hline
\end{tabular}


Table 1. Cont.

\begin{tabular}{|c|c|c|c|c|}
\hline Strain Name & Isolation Year & Origin * & Host Plant & Species Definition \\
\hline E. chrysanthemi CH93/38-165-1 & 1993 & $\mathrm{CH}$ & S. tuberosum cv. Urgenta & D. dianthicola \\
\hline E. chrysanthemi CH93/38-188-3 & 1993 & $\mathrm{CH}$ & S. tuberosum cv. Désirée & D. dianthicola \\
\hline E. chrysanthemi CH93/38-317-4 & 1993 & $\mathrm{CH}$ & S. tuberosum cv. Eba & D. chrysanthemi \\
\hline E. chrysanthemi CH93/40-24-1 & 1993 & $\mathrm{CH}$ & S. tuberosum cv. Granola & D. chrysanthemi \\
\hline E. chrysanthemi CH93/40-83-1 & 1993 & $\mathrm{CH}$ & S. tuberosum cv. Bintje & D. dianthicola \\
\hline E. chrysanthemi CH91/87-1 & 1994 & $\mathrm{CH}$ & S. tuberosum cv. Désirée & D. dianthicola \\
\hline E. chrysanthemi CH94/71-1 & 1994 & $\mathrm{CH}$ & Zea mays & D. dianthicola \\
\hline E. chrysanthemi $\mathrm{CH} 94 / 71-3$ & 1994 & $\mathrm{CH}$ & Zea mays & D. dianthicola \\
\hline E. chrysanthemi CH33 Jäggi & 1995 & $\mathrm{CH}$ & unknown & D. dianthicola \\
\hline E. chrysanthemi CH96/35-1 & 1996 & NL & S. tuberosum cv. Agria & D. solani \\
\hline E. chrysanthemi CH96/35-2 & 1996 & NL & S. tuberosum cv. Agria & D. dianthicola \\
\hline E. chrysanthemi CH96/36-1 & 1996 & NL & S. tuberosum cv. Agria & D. dianthicola \\
\hline E. chrysanthemi CH97/29-295 & 1997 & $\mathrm{CH}$ & S. tuberosum cv. Erntestolz & D. dianthicola \\
\hline E. chrysanthemi CH97/29-309 & 1997 & $\mathrm{CH}$ & S. tuberosum cv. Erntestolz & D. dianthicola \\
\hline E. chrysanthemi CH98/10 & 1998 & NL & S. tuberosum cv. Agria & D. chrysanthemi \\
\hline E. chrysanthemi CH99/18-774 & 1999 & NL & S. tuberosum cv. Eba & D. solani \\
\hline CH05026 & 2005 & $\mathrm{CH}$ & S. tuberosum cv. Agria & D. solani \\
\hline CH07044 & 2007 & $\mathrm{CH}$ & S. tuberosum cv. Tripla & D. solani \\
\hline $\mathrm{IPO}_{2222^{\mathrm{T}}}$ & 2007 & NL & S. tuberosum & D. solani \\
\hline 3337 & 2008 & France & S. tuberosum & D. solani \\
\hline
\end{tabular}

* Abbreviations: CH: Switzerland, NL: The Netherlands.

\subsection{Genome Sequencing and Assembly}

To analyse the diversity of the early $D$. solani strains, genome sequencing was performed at the next-generation sequencing core facilities of the Institute for Integrative Biology of the Cell (Avenue de la Terrasse, 91190 Gif-sur-Yvette, France). Nextera DNA libraries were prepared from $50 \mathrm{ng}$ of high-quality genomic DNA. Paired-end $2 \times 75 \mathrm{pb}$ sequencing was performed on an Illumina NextSeq500 apparatus, with a High Output 150 cycle kit. CLC Genomics Workbench (Version 9.5.2, Qiagen Bioinformatics, Hilden, Germany) was used to assemble reads. Final sequencing coverage was between 49 and 79 (Table 1). Coding sequences were predicted using the RAST server [21] with the Glimmer 3 prediction tool [22]. Besides the two D. solani strains isolated before 2000, we sequenced two D. solani isolated in Switzerland during the 2005-2013 outbreak, CH05026 and CH07044. Statistics of these newly sequenced draft genomes are presented in Table 2.

Table 2. Draft genome sequences of Dickeya solani strains isolated in Switzerland.

\begin{tabular}{|c|c|c|c|c|c|c|}
\hline Strain & Accession Number & Genome Size & $\begin{array}{l}\text { Number of } \\
\text { Contigs }\end{array}$ & Coverage & $\begin{array}{c}\text { Number of } \\
\text { CDS }\end{array}$ & $\begin{array}{c}\text { Number of } \\
\text { tRNAs }\end{array}$ \\
\hline CH9635-1 & GCA_016404945.1 & $4,872,960$ & 52 & $58 \times$ & 4149 & 51 \\
\hline CH9918-774 & GCA_016404885.1 & $4,881,636$ & 72 & $49 \times$ & 4160 & 49 \\
\hline CH05026 & GCA_016404895.1 & $4,874,174$ & 52 & $65 \times$ & 4146 & 54 \\
\hline $\mathrm{CH} 07044$ & GCA_016404925.1 & $4,878,125$ & 39 & $79 \times$ & 4133 & 61 \\
\hline
\end{tabular}

\subsection{Genome Analysis}

Pairwise comparison of the genomes was computed using the average nucleotide identity (ANI) Pyani python module (https: / /github.com/widdowquinn/pyani [23], accessed on 21 May 2021) with the blast algorithm (ANIb). The species threshold was set at $96 \%$.

Single nucleotide polymorphisms (SNPs) were detected with the CLC Genomics Workbench (basic variant detection tool) after mapping Illumina reads onto reference genome.

Orthologous sequences were clustered into homologous families using the SiLix software package [24], with a 70\% identity threshold and at least $80 \%$ overlap. Strainspecific gene families and gene families absent in only one of the six analysed genomes were extracted from the SiLix output. Since draft genomes were analysed, the presence and position of those specific and absent genes were manually inspected to detect split and 
truncated genes due to their location at the end of contigs as well as genes detected on very small contigs of a few hundred nucleotides.

\subsection{Aggressiveness Assays}

Bacterial strains were plated on $\mathrm{LB}^{-}$plates, incubated for $16 \mathrm{~h}$ at $28{ }^{\circ} \mathrm{C}$ and resuspended in $\mathrm{KPO}_{4} 50 \mathrm{mM}$ pH 7.0 buffer. After wounding with a yellow tip, potato tubers and detached chicory leaves were inoculated with $2.10^{6}$ bacteria and incubated at $26^{\circ} \mathrm{C}$ in closed boxes to allow high humidity. After five days incubation, symptoms on potato tubers were categorised according to the following scale: 1 : maceration zone $<2 \mathrm{~mm}$; 2 : maceration zone $<5 \mathrm{~mm}$; 3 : maceration zone $<10 \mathrm{~mm}$; and 4 : maceration zone $>10 \mathrm{~mm}$. For chicory leaves, measuring the length of rotted tissue after $24 \mathrm{~h}$ incubation assessed disease severity. Both assays were carried out in triplicate.

\section{Results}

\subsection{The Swiss Collection of E. chrysanthemi}

From 1985 to 2000, Agroscope Changins collected bacterial isolates mostly originating from symptomatic potato plant material sampled by Swiss organisations of certified seed potato production (VOZ, SEMAG, SGD, ASS and SGSG). The samples were gathered either by these organisations in pre-basic, basic and certified symptomatic material or by accredited field inspectors as part of the certification process. Most bacterial strains were isolated from blackleg-harbouring stems. In a few cases, they were isolated from macerated tubers; this is the case for the few strains isolated from imported certified seeds (marked NL in Table 1). All other isolates originated from plant material grown in Switzerland. Besides strains isolated from potatoes, the Swiss collection also included three strains isolated from other hosts (Table 1). These strains were identified as E. chrysanthemi using biochemical and ELISA immunological tests $[14,15,25]$.

\subsection{Diversity of the Pectinolytic Dickeya Isolated in Switzerland}

The genus/species assignation of strains from the Swiss collection was analysed by amplification and sequencing of the gap $A$ housekeeping gene recently shown to clearly differentiate the different Dickeya species [16] (Figure 1). Out of the 82 strains analysed, only 5 do not belong to the Dickeya genus, confirming the discriminative power of the biochemical and serological tests used to determine phylogenetic appurtenance before the advent of genetic tools. Three of these strains cluster with Pectobacterium, the other genus grouping pectinolytic bacteria commonly involved in potato blackleg disease. These include two strains belonging to $P$. versatile, a species recently described to have a very broad host range [26] and one strain belonging to P. parmentieri, another recently described species that was, however, present in potatoes in Poland from the 1990s [27,28]. More unexpectedly, two strains closely cluster with Rahnella aquatilis, a gammaproteobacterium whose genus members have been isolated from soil, freshwater and food, but also clinical samples [29]. Genomic search into the genome of the R. aquatilis type strain CIP 78.65 revealed the presence of genes encoding enzymes involved in pectin degradation: a pectin methyl esterase similar to PemB (52\% identity /67\% similarity), an exo-polygalacuronate lyase similar to PelX (54\% identity /68\% similarity) as well as the oligogalacturonide lyase Ogl (68\% identity / 82\% similarity) and the various proteins involved in oligalacturonides transport and metabolism. Some Rahnella strains also encode a polygalacturonase showing limited similarity with D. solani PehN (32\% identity/44\% similarity in EMR1.05), albeit missing in CIP 78.65. This indicates that Rahnella strains indeed may possess the enzymatic arsenal to degrade pectin. 


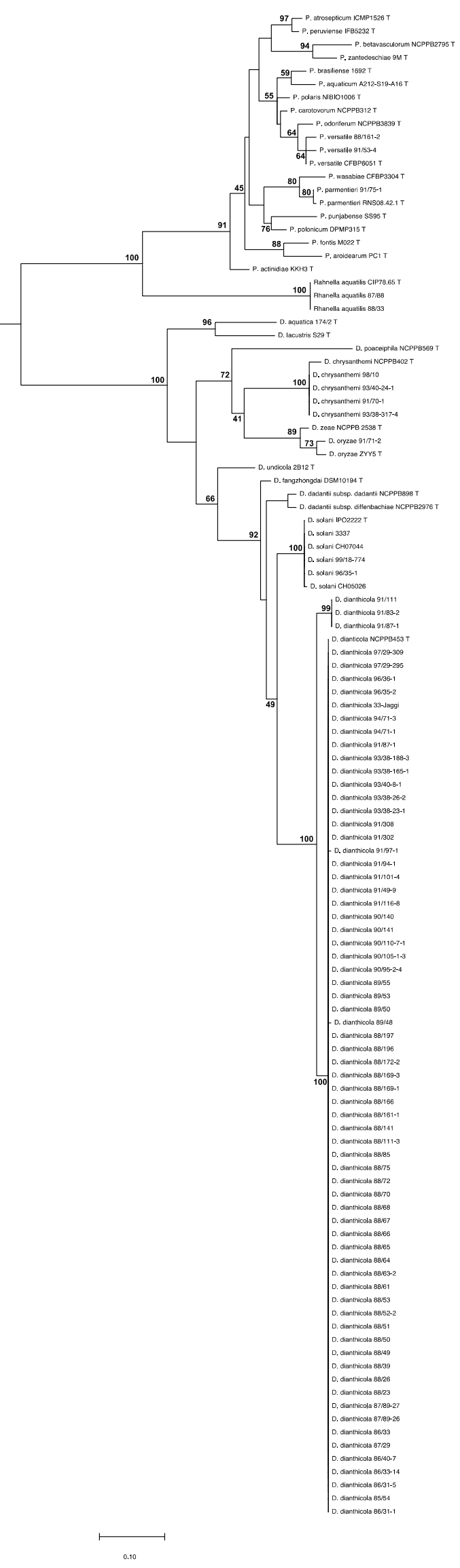

Figure 1. Phylogeny of strains from the Swiss collection. Phylogenic tree built up from a 799 nucleotide sequence of the housekeeping gapA gene using the PhyML option of the SeaView platform program (200 bootstraps). 
Among the 75 remaining isolates, in accordance with data from previous analyses of European Dickeya collections [8,9], 70 clustered with the D. dianthicola type strain NCPPB453. These strains are highly related since all of them but three share identical gap $A$ sequences or harbour only one substitution (Figure 1). However, our analysis revealed two interesting features. The first one is the presence in the Swiss collection of four D. chrysanthemiisolated in three different years, and one D. oryzeae strains (Figure 1 and Table 1). The second one is the occurrence of $D$. solani strains infecting potato as early as 1996, about a decade before this species was isolated in Europe [9].

\subsection{Genomic Analysis of the Early D. solani}

D. solani is known to be very clonal since most strains isolated either from potatoes or from ornamentals in the 2000s only harbour a few SNPs differences between them [30]. The presence of two early D. solani strains isolated in 1996 (CH9635-1) and 1999 (CH9918-774) in the Swiss collection (Table 1), long before this species caused the major outbreak that Europe faced later in the 2000s [7], prompted us to analyse the genomic differences that might be present as compared to epidemic D. solani strains isolated in the 2000s. For this, using Illumina technology, we sequenced the genomes of these two early strains as well as two other strains isolated in Switzerland after occurrence of the outbreak in Europe in 2005 (CH05026) and 2007 (CH07044). Characteristics of the draft genomes are presented in Table 2.

We compared these four genomes with the ones of the type strain IPO2222 isolated in The Netherlands [13] and of the well-described French strain 3337 [31,32]. Average nucleotide identity (ANI) analysis revealed that these six strains are highly similar with ANI percentage between them, ranging from 99.96 to $100 \%$ with a high percentage of all compared genomes being successfully aligned (99.03 to 99.99\%). As already described [28], we refined this analysis by mapping the Illumina reads of the four Swiss genomes to the 3337 complete genome, allowing us to identify SNPs and InDels variations. The four Swiss strains only exhibit 53 to 94 SNPs/InDels, among which 49 are common to the four Swiss strains, indicating they are specific to the 3337 genome (Table 3). The noncommon SNP/InDels are found in very few genes (Table 3). The higher number of SNPs found in strain CH07044 comes from SNPs that are clustered in one gene encoding a methyl-accepting chemotaxis protein (23 SNPs). In addition, 99.7 to $99.9 \%$ of the four Swiss genomes reads mapped to the 3337 genome, indicating that these strains do not possess inserted or extrachromosomal regions absent from 3337.

Table 3. SNP/InDels variations present in the Swiss strains.

\begin{tabular}{|c|c|c|c|c|}
\hline Strains & CH9635-1 & СH9918-774 & CH05026 & CH07044 \\
\hline $\begin{array}{l}\text { \# SNP / InDels } \\
\text { common }\end{array}$ & \multicolumn{4}{|c|}{$47 / 2$} \\
\hline remaining & $10 / 1$ & $4 / 0$ & $7 / 1$ & $39 / 6$ \\
\hline \# intergenic & $1 / 1$ & $1 / 0$ & $1 / 1$ & $3 / 3$ \\
\hline$\#$ in tRNA & - & 1 & 1 & 2 \\
\hline$\#$ in CDS & $9 / 0$ & $2 / 0$ & $5 / 0$ & $34 / 3$ \\
\hline neutral & 8 & 2 & 4 & 29 \\
\hline aa change & 1 & - & 1 & 5 \\
\hline frame shift & - & - & - & 3 \\
\hline \# of affected CDS & 4 & 2 & 5 & 5 \\
\hline
\end{tabular}

To further compare the gene content of the different D. solani genomes analysed here, we performed a comparative genomic analysis of the protein coding sequences of these six genomes, using the SiLix gene family clustering tool. Proteins were classified as homologous to another in a given family if the amino acid identities were above $70 \%$ on at least $80 \%$ of the full-length amino acid sequence. Out of the 4488 to 4496 protein families present in the different strains, 4272 (95.0 to 95.6\%) are common to all six genomes, again pointing to the very high closeness between the strains. This was confirmed by 
the identification of protein families that are either present only in one strain out of the six analysed genomes (called specific) or absent in a given strains while present in the five other analysed genomes. The different strains harbour at most a few dozen specific protein families under SiLix analysis, and when screened to eliminate those resulting from sequence problems in the draft genomes (see Material and Methods), only 3 to 17 specific protein families were detected (Table 4). The vast majority of them are small (less than 100 aa) hypothetical proteins. The putative function of the remaining ones is presented in Table 4. None of these specific protein families was reported to be involved in interactions with host plants. Similarly, we detected very few protein families specifically absent in a given strain (5 to 9), and the vast majority of them are small hypothetical proteins (Table 4).

Table 4. Specific/absent protein families in Swiss D. solani.

\begin{tabular}{|c|c|c|c|}
\hline Strains & Protein Family Number & Hypothetical(*) & With Known Function \\
\hline \multicolumn{4}{|c|}{ Specific protein families } \\
\hline CH9635-1 & 17 & $16(2)$ & VgrG \\
\hline CH9918-774 & 14 & 9 & $\begin{array}{c}\text { Mobile element protein } \\
2 \text { truncated ABC transporter permease } \\
2 \text { truncated cellulose synthase CbsC }\end{array}$ \\
\hline $\mathrm{CH} 05026$ & 3 & 3 & \\
\hline $\mathrm{CH} 07044$ & 8 & $8(1)$ & \\
\hline Dso3337 & 14 & 6 & $\begin{array}{c}2 \text { phage-related } \\
2 \text { truncated aconitate hydratase } 2 \\
2 \text { truncated PotA ABC transporter } \\
2 \text { truncated VgrG }\end{array}$ \\
\hline IPO2222 & 10 & $10(4)$ & \\
\hline \multicolumn{4}{|c|}{ Absent protein families } \\
\hline CH9635-1 & 7 & $7(2)$ & \multirow{4}{*}{$\mathrm{ABC}$ transporter permease (truncated) } \\
\hline CH9918-774 & 7 & 6 & \\
\hline CH05026 & 9 & 9 & \\
\hline CH07044 & 8 & 8 & \\
\hline & & & 1 phage-related \\
\hline Dso3337 & 5 & 2 & Ferredoxin \\
\hline IPO2222 & 8 & 4 & $\begin{array}{l}\text { PotA ABC transporter } \\
2 \text { phage-related proteins } \\
\text { regulator YfeR (truncated) } \\
\text { truncated CmaU-related protein }\end{array}$ \\
\hline
\end{tabular}

$\left({ }^{*}\right)$ Number of protein families quoted as specific because of difference in respective length exceeding $80 \%$.

\subsection{Aggressiveness of Early D. solani}

Our genomic analysis revealed that the early $D$. solani possess all the genes known to be involved in virulence. However even highly closely related $D$. solani strains might vary a lot in their aggressiveness [33]. To test this, we compare the aggressiveness of the two early D. solani strains with that of the type strain IPO2222 on both potato tubers and chicory. On both plants, these strains were as aggressive as IPO2222 (Figure 2). 
A.
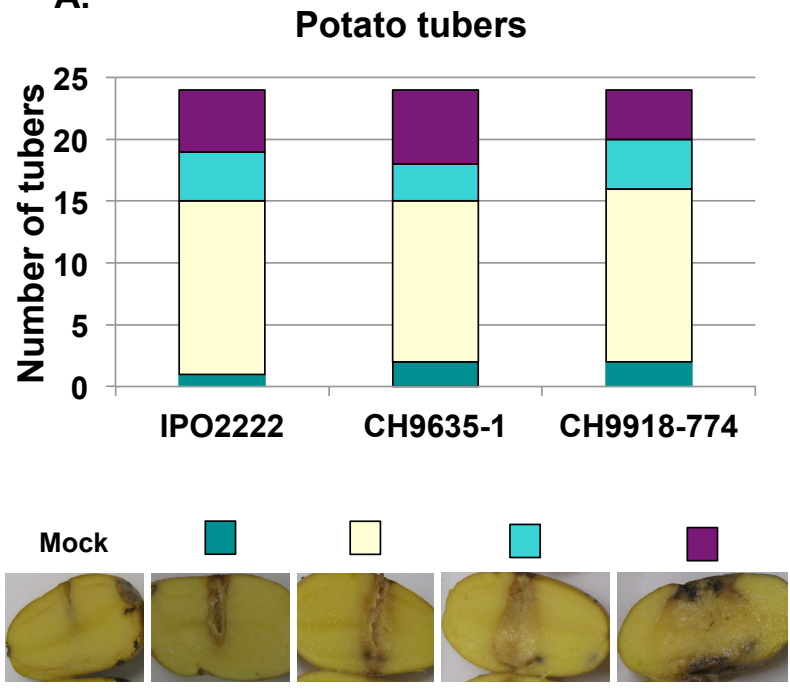

B.

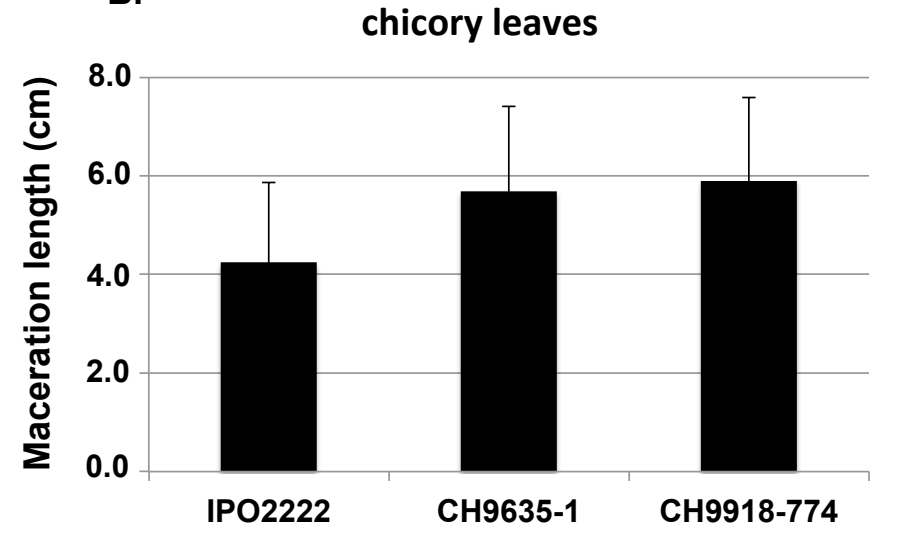

Figure 2. Aggressiveness of early D. solani strains on potato tubers and chicory leaves. For potato (A), symptoms were assigned to four classes according to the extent of maceration five days post inoculation (see Material and Methods). Pictures present examples of the typology of each class. For chicory leaves (B), disease severity was assessed by measuring the length of macerated tissue $24 \mathrm{~h}$ post inoculation. Assays were performed in triplicate, and the results were pooled.

\section{Discussion}

The population dynamics of potato blackleg causing SRP is different in Switzerland as compared to in other European countries with a high incidence (60 up to $90 \%$ ) of Dickeya species (at the time called E. chrysanthemi) already in the 1980s [15]. To pinpoint what may underlie this Swiss peculiarity, we analysed the diversity present in the E. chrysanthemi Agroscope collection gathering isolates from 1985 to 1990 and identified the majority of isolates as $D$. dianthicola, but also a few isolates as D. chrysanthemi and D. oryzeae and, interestingly, two "early" D. solani isolated in the 1990s from potato seeds imported from The Netherlands.

Such a high proportion of $D$. dianthicola isolates is in concordance with previous studies stating that this species was the Dickeya genus representative that emerged in the 1970s in potato cultures in other European countries, including those from which potato seeds are commonly imported by Switzerland [7-9]. The gap $A$ analysis revealed a very high closeness between the Swiss D. dianthicola isolates. Indeed, for 67 out of 70 strains, the gap $A$ sequence is identical to or only shows one SNP as compared to the NCPPB453 type strain gapA sequence. Only three strains harbour a slightly different sequence (23 SNP out of 799 nucleotides). This points to a high closeness between $D$. dianthicola potato pathogens that is consistent with the high homogeneity of the $D$. dianthicola genomes publicly available that show average nucleotide identities (ANI) of more than $99 \%$ between them [34]. It should be noted, however, that, except for the type strain isolated from carnation, all $D$. dianthicola genomes available are from potato isolates. It would thus be interesting to further analyse $D$. dianthicola genomic diversity by including isolates from other plants attacked by this wide host range pathogen.

Previous analyses of collections of Dickeya strains isolated from potato ([8,9]; 56 and 65 strains analysed, respectively) revealed the presence of only D. dianthicola in Europe before the occurrence of $D$. solani in the 2000s, with the exception of two D. dadantii strains isolated in Germany [9]. Out of the twelve Dickeya species described to date, five have been identified on potatoes, and they appear to be distinct on different continents [2]. Besides Europe, D. dianthicola was reported in Russia [2], Bangladesh [8], Pakistan [35] and Morocco [36] and has recently been determined to be responsible for a recent outbreak in the USA [37]; D. solani was also reported in Israel, Turkey, Russia, Brazil and Chile [13,38,39]; D. chrysanthemi in the USA and Taiwan [8,9,40]; D. dadantii in Brazil [8], 
Peru [9,41], Zimbabwe [42] and the USA [40]; and D. zeae/D. oryzae in Australia and Papua New Guinea $[8,9,43,44]$. Here, we showed that $D$. chrysanthemi and D. oryzeae could also be responsible for potato blackleg disease in Europe, even if much less frequently than $D$. dianthicola at the time. This broadens the spectrum of Dickeya species isolated from potatoes in Europe and highlights the need to not be too restrictive in the detection campaigns by only testing for the predominant species responsible for blackleg.

The other interesting finding of this study is the identification of D. solani strains isolated about a decade before the representatives of this species in analysed collections that were isolated during the major outbreak that spread over Europe and Israel from 2005. These early strains are highly closely related to the epidemic clones isolated later during the 2000s outbreak, harbouring very few SNP variations and differences in gene content (Tables 3 and 4). Among these rare genomic variations, there is no linking evidence for the involvement in interactions with plants, and virulence tests revealed these early isolates to be as aggressive as the $D$. solani type strain on tubers and chicory leaves (Figure 2). Our data thus highlight the presence of potentially aggressive $D$. solani in potato seeds already in the last century, and we may wonder why it did not lead to an earlier outbreak. Though this a complex question, we may put forward a few assumptions. First, the seed lots carrying these early $D$. solani were contaminated to such levels that they were rejected for planting; if such high seed tuber symptoms were the rule for these strains, we may assume that these bacteria were not further disseminated in fields. Since the severity of diseases caused by SRP is highly dependent on temperature and humidity conditions [6,7], another possibility would be that the environmental conditions encountered by contaminated lots in further planting were not conducive enough to allow massive multiplication and spread. Finally, despite the clonal nature of $D$. solani, very few genomic differences between isolates might result in large differences in aggressiveness [33]. Even if the early D. solani are able to efficiently attack plants in laboratory conditions, we cannot rule out that subtle genomic changes may render these strains less efficient in colonisation or latent survival before disease expression. These aspects of the pathogen's life cycle might be important for the comprehension of outbreak occurrence and should certainly be further investigated.

In conclusion, this work revealed that a broader than previously reported range of Dickeya species could be encountered on diseased potatoes in Europe, pointing to other putative actors in the population dynamics that has been observed in this crop for decades. It also reported the presence of D. solani in potatoes in as early as the 1990s. These early strains, such as the epidemic clones already analysed, only harboured very few genomic variations as compared to strains isolated during the large European outbreak of the beginning of this century. This further confirms the clonality of $D$. solani strains isolated from potatoes over time and, therefore, the remarkable stability of the genome of this species over more than two decades.

Author Contributions: Conceptualization, F.V.G.; methodology, J.P. and F.V.G.; formal analysis, J.P. and F.V.G.; resources, S.S. and I.K.; writing-original draft preparation, F.V.G.; writing-review and editing, J.P., S.S. and F.V.G. All authors have read and agreed to the published version of the manuscript.

Funding: This research was supported by the project COMBICONTROL ((ANR-17-CE32-0004-04) financed by the French National Agency for Research.

Institutional Review Board Statement: Not applicable.

Informed Consent Statement: Not applicable.

Data Availability Statement: The datasets generated for this study are available in Table 2.

Conflicts of Interest: The authors declare no conflict of interest. 


\section{References}

1. $\quad$ van der Wolf, J.M.; De Boer, S.H. Bacterial pathogens of potato. In Potato Biology and Biotechnology: Advances and Perspectives; Vreugdenhil, D., Ed.; Elsevier: Oxford, UK, 2007; pp. 595-617.

2. $\quad$ van der Wolf, J.M.; Acuña, I.; De Boer, S.H.; Brurberg, M.H.; Cahill, G.; Charkowski, A.O.; Coutinho, T.; Davey, T.; Dees, M.W.; Degefu, Y.Y.; et al. Diseases Caused by Pectobacterium and Dickeya Species Around the World. In Plant Diseases Caused by Pectobacterium and Dickeya Species; Van Gijsegem, F., van der Wolf, J.M., Toth, I.K., Eds.; Springer Nature: Cham, Switzerland, 2021; pp. 215-262.

3. Charkowski, A.; Blanco, C.; Condemine, G.; Expert, D.; Franza, T.; Hayes, C.; Hugouvieux-Cotte-Pattat, N.; López Solanilla, E.; Low, D.; Moleleki, L.; et al. The role of secretion systems and small molecules in soft-rot Enterobacteriaceae pathogenicity. Annu. Rev. Phytopathol. 2012, 50, 425-449. [CrossRef]

4. Reverchon, S.; Nasser, W. Dickeya ecology, environment sensing and regulation of virulence programme. Environ. Microbiol. Rep. 2013, 5, 622-636.

5. Van Gijsegem, F.; Hugouvieux-Cotte-Pattat, N.; Kraepiel, Y.; Lojkowska, E.; Moleleki, L.; Gorshkov, V.; Yedidia, I. Molecular interactions of Pectobacterium and Dickeya with plants. In Plant Diseases Caused by Pectobacterium and Dickeya Species; Van Gijsegem, F., van der Wolf, J.M., Toth, I.K., Eds.; Springer Nature: Cham, Switzerland, 2021; pp. 85-148.

6. Pérombelon, M.C.M. Potato diseases caused by soft rot erwinias: An overview of pathogenesis. Plant Pathol. $2002,51,1-12$.

7. Toth, I.K.; van der Wolf, J.M.; Saddler, G.; Lojkowska, E.; Hélias, V.; Pirhonen, M.; Tsror (Lahkim), L.; Elphinstone, J.G. Dickeya species: An emerging problem for potato production in Europe. Plant Pathol. 2011, 60, 385-399. [CrossRef]

8. Parkinson, N.; Stead, D.; Bew, J.; Heeney, J.; Tsror, L.; Elphinstone, J. Dickeya species relatedness and clade structure determined by comparison of recA sequences. Int. J. Syst. Bacteriol. 2009, 59, 2388-2393. [CrossRef]

9. Sławiak, M.; van Beckhoven, J.R.C.M.; Speksnijder, A.G.C.L.; Czajkowski, R.; Grabe, G.; van der Wolf, J.M. Biochemical and genetical analysis reveal a new clade of biovar 3 Dickeya spp. strains isolated from potato in Europe. Eur. J. Plant Pathol. 2009, 125, 245-261. [CrossRef]

10. Hellmers, E. Four wilt diseases of perpetual flowering carnations in Denmark. Dansk Botanisk Arkiv. 1958, 18, 95-140.

11. Czajkowski, R.; Grabe, G.J.; van der Wolf, J.M. Distribution of Dickeya spp. and Pectobacterium carotovorum subsp. carotovorum in naturally infected seed potatoes. Eur. J. Plant Pathol. 2009, 125, 263-275. [CrossRef]

12. Tsror, L.; Erlich, O.; Lebiush, S.; Hazanovsky, M.; Zig, U.; Slawiak, M.; Grabe, G.; van der Wolf, J.M.; Van de Haar, J.J. Assessment of recent outbreaks of Dickeya sp. (syn. Erwinia chrysanthemi) slow wilt in potato crops in Israel. Eur. J. Plant Pathol. 2009, 123, 311-320. [CrossRef]

13. Van der Wolf, J.M.; Nijhuis, E.H.; Kowalewska, M.J.; Saddler, G.S.; Parkinson, N.; Elphinstone, J.G.; Pritchard, L.; Toth, I.K.; Lojkowska, E.; Potrykus, M.; et al. Dickeya solani sp. nov., a pectinolytic plant-pathogenic bacterium isolated from potato (Solanum tuberosum). Int. J. Syst. Evol. Microbiol. 2014, 64, 768-774. [CrossRef]

14. Cazelles, O.; Schwarzel, R. Survey of bacterial diseases caused by Erwinia in seed potato fields in western Switzerland. Rev. Suisse Agric. 1992, 24, 215-218.

15. de Werra, P.; Bussereau, F.; Kellenberger, I.; Dupuis, B.; Schaerer, S.; Keiser, A. Pomme de terre: L'Empire Pectobacterium contre-attaque. Rech. Agron. Suisse 2015, 6, 256-263.

16. Cigna, J.; Dewaegeneire, P.; Beury, A.; Gobert, V.; Faure, D. A gapA PCR-sequencing Assay for Identifying the Dickeya and Pectobacterium Potato Pathogens. Plant Dis. 2017, 101, 1278-1282. [CrossRef]

17. Edgar, R.C. MUSCLE: Multiple sequence alignment with high accuracy and high throughput. Nucleic Acids Res. 2004, 32, 1792-1797. [CrossRef]

18. Castresana, J. Selection of Conserved Blocks from Multiple Alignments for Their Use in Phylogenetic Analysis. Mol. Biol. Evol. 2000, 17, 540-552. [CrossRef]

19. Tamura, K.; Neii, M. Estimation of the number of nucleotide substitutions in the control region of mitochondrial DNA in humans and chimpanzees. Mol. Biol. Evol. 1993, 10, 512-526.

20. Gouy, M.; Guindon, S.; Gascuel, O. SeaView Version 4: A Multiplatform Graphical User Interface for Sequence Alignment and Phylogenetic Tree Building. In Molecular Biology and Evolution; Oxford University Press: Oxford, UK, 2010; Volume 27, pp. 221-224.

21. Aziz, R.K.; Bartels, D.; Best, A.A.; DeJongh, M.; Disz, T.; Edwards, R.A.; Formsma, K.; Gerdes, S.; Glass, E.M.; Kubal, M.; et al. The RAST Server: Rapid annotations using subsystems technology. BMC Genom. 2008, 9, 75. [CrossRef]

22. Delcher, A.L.; Harmon, D.; Kasif, S.; White, O.; Salzberg, S.L. Improved microbial gene identification with GLIMMER. Nucleic Acids Res. 1999, 27, 4636-4641. [CrossRef]

23. Pritchard, L.; Glover, R.H.; Humphris, S.; Elphinstone, J.G.; Toth, I.K. Genomics and taxonomy in diagnostics for food security: Soft-rotting enterobacterial plant pathogens. Anal. Methods 2016, 8, 12-24. [CrossRef]

24. Miele, V.; Penel, S.; Duret, L. Ultra-fast sequence clustering from similarity networks with SiLiX. BMC Bioinform. 2011, 12, 116. [CrossRef]

25. Cazelles, O. Survey of Dickeya on potato in Switzerland. In Proceedings of the EAPR 11th Triennial Conference, Edinburgh, UK, 8-13 July 1990; pp. 325-326.

26. Portier, P.; Pédron, J.; Taghouti, G.; Fischer-Le Saux, M.; Caullireau, E.; Bertrand, C.; Laurent, A.; Chawki, K.; Oulgazi, S.; Moumni, M.; et al. Elevation of Pectobacterium carotovorum subsp. odoriferum to species level as Pectobacterium odoriferum sp. nov., 
proposal of Pectobacterium brasiliense sp. nov. and Pectobacterium actinidiae sp. nov., emended description of Pectobacterium carotovorum and description of Pectobacterium versatile sp. nov., isolated from streams and symptoms on diverse plants. Int. J. Syst. Evol. Microbiol. 2019, 69, 3207-3216. [PubMed]

27. Khayi, S.; Cigna, J.; Chong, T.; Quêtu-Laurent, A.; Chan, K.; Helias, V.; Faure, D. Transfer of the potato plant isolates of Pectobacterium wasabiae to Pectobacterium parmentieri sp. nov. Int. J. Syst. Evol. Microbiol. 2016, 66, 5379-5383. [CrossRef]

28. Motyka-Pomagruk, A.; Zoledowska, S.; Sledz, W.; Lojkowska, E. The occurrence of bacteria from different species of Pectobacteriaceae on seed potato plantations in Poland. Eur. J. Plant Pathol. 2021, 159, 309-325. [CrossRef]

29. Martinez, R.J.; Bruce, D.; Detter, C.; Goodwin, L.A.; Han, J.; Han, C.S.; Held, B.; Land, M.L.; Mikhailova, N.; Nolan, M.; et al. Complete Genome Sequence of Rahnella aquatilis CIP 78. J. Bacteriol. 2012, 194, 3020-3021. [CrossRef]

30. Khayi, S.; Blin, P.; Pédron, J.; Chong, T.M.; Chan, K.G.; Moumni, M.; Hélias, V.; Van Gijsegem, F.; Faure, D. Population genomics reveals additive and replacing horizontal gene transfers in the emerging pathogen Dickeya solani. BMC Genom. 2015, 16, 788. [CrossRef] [PubMed]

31. Pédron, J.; Mondy, S.; Raoul des Essarts, Y.; Van Gijsegem, F.; Faure, D. Genomic and metabolic comparison with Dickeya dadantii 3937 reveals the emerging Dickeya solani potato pathogen to display distinctive metabolic activities and T5SS/T6SS-related toxin repertoire. BMC Genom. 2014, 15, 283. [CrossRef] [PubMed]

32. Raoul des Essarts, Y.; Pédron, J.; Blin, P.; Van Dijk, E.; Faure, D.; Van Gijsegem, F. Common and distinctive adaptive traits expressed in Dickeya dianthicola and Dickeya solani pathogens when exploiting potato plant host. Environ. Microbiol. 2019, 21, 1004-1018. [CrossRef] [PubMed]

33. Golanowska, M.; Potrykus, M.; Motyka-Pomagruk, A.; Kabza, M.; Bacci, G.; Galardini, M.; Bazzicalupo, M.; Makalowska, I.; Smalla, K.; Lojkowska, E.; et al. Comparison of highly and weakly virulent Dickeya solani strains, with a view on the pangenome and panregulon of this species. Front. Microbiol. 2018, 9, 1940. [CrossRef]

34. Pédron, J.; Van Gijsegem, F. Diversity in the Bacterial Genus Dickeya Grouping Plant Pathogens and Waterways Isolates. OBM Genet. 2019, 3, 22. [CrossRef]

35. Sarfraz, S.; Riaz, K.; Oulghazi, S.; Cigna, J.; Alam, M.W.; Dessaux, Y.; Faure, D. First report of Dickeya dianthicola causing blackleg disease on potato plants in Pakistan. Plant Dis. 2018, 102, 2027-2028. [CrossRef]

36. Oulghazi, S.; Khayi, S.; Lafkih, N.; Massaoudi, Y.; El Karkouri, A.; El Hassouni, M.; Faure, D.; Moumni, M. First report of Dickeya dianthicola causing blackleg on potato in Morocco. Plant Dis. 2017, 101, 1671-1672. [CrossRef]

37. Charkowski, A.O. The changing face of bacterial soft-rot diseases. Annu. Rev. Phytopathol. 2018, 56, 269-288. [CrossRef]

38. Ozturk, M.; Aksoy, H.M. First report of Dickeya solani associated with potato blackleg and soft rot in Turkey. J. Plant Pathol. 2017, 99,298

39. Cardoza, Y.F.; Duarte, V.; Lopes, C.A. First report of blackleg of potato caused by Dickeya solani in Brazil. Plant Dis. 2017, 101, 243. [CrossRef]

40. McNally, R.R.; Curland, R.D.; Webster, B.T.; Robinson, A.P.; Ishimaru, C.A. First report of stem rot on potato caused by Dickeya chrysanthemi in Minnesota. Plant Dis. 2018, 102, 238. [CrossRef]

41. DeLindo, L.; French, E. Erwinia species attacking potato in the humid tropics of Peru. Fitopatologia 1981, 16, 69-74.

42. Ngadze, E.; Coutinho, T.A.; van der Waals, J.E. First report of soft rot of potatoes caused by Dickeya dadantii in Zimbabwe. Plant Dis. 2010, 94, 1263. [CrossRef] [PubMed]

43. Cother, E.J. Bacterial seed tuber decay in irrigated sandy soils of New South Wales. Potato Res. 1980, 23, 75-84. [CrossRef]

44. Cother, E.J.; Bradley, J.K.; Gillings, M.R.; Fahy, P.C. Characterization of Erwinia chrysanthemi biovars in alpine water sources by biochemical properties, GLC fatty acid analyses and genomic DNA fingerprinting. J. Appl. Bacteriol. 1992, 73, 99-107. [CrossRef] 